\title{
Makna Tanda Novela Antoine De Saint-Exupéry
}

\author{
Angga Intueri Mahendra P \\ Program Studi Ilmu Komunikasi, Universitas AMIKOM Yogyakarta \\ email: angga_intuery@amikom.ac.id
}

Cara Sitasi: Angga, I M P (2021), Makna Tanda Novela Antoine De Saint-Exupéry (2021) 21 (1), 32-38

Retrieved from https://doi.org/10.31294/jc.v19i2

\begin{abstract}
The work of fiction has many signs and meanings are different for each reader. Signs could reflect what might happen in real life, such as the about communication. Similarly as novella titled The Little Prince by Antoine de Saint-Exupéry which have a lot of interpretations. As a result of the extensive interpretation, a lot of readers do not understand what the thing to be conveyed by the author. Therefore, this study looked for signs that confuse the reader and interpret it using semiotics by Charles Sanders Peirce. The study also outlines the signs associated with intrapersonal and interpersonal communication in real life, especially studied of Symbolic Interaction Theory and Coordinated Management of Meaning.
\end{abstract}

\section{Keywords: Semiotic, Intrapersonal Communication, Interpersonal Communication}

\section{PENDAHULUAN}

Pada tahun 1943 di Prancis, terbit sebuah novela berjudul Le Petit Prince. Novela ini ditulis oleh seorang penulis, penyair, sekaligus penerbang bernama Antoine de Saint-Exupéry. Novela ini telah diterjemahkan ke dalam lebih dari 250 bahasa di seluruh dunia, membuatnya menjadi buku keempat yang paling banyak diterjemahkan di dunia (Shattuck: 2005). Penjualan yang mencapai lebih dari 140 juta salinan, juga membuatnya menjadi salah satu buku paling laris di dunia. Buku ini diterjemahkan menjadi The Little Prince dalam bahasa Inggris dan Pangeran Cilik dalam bahasa Indonesia. Selanjutnya, dalam jurnal ini akan menggunakan judul Pangeran Cilik sebagai pengganti judul asli.

Penelitian ini melihat, ada tanda-tanda dan pemaknaan yang luas dalam Pangeran Cilik. Jika dilihat dari sisi pembaca, dapat ditemukan beberapa bagian dari tanda Saint-Exupéry yang sulit untuk dipahami. Kesulitan ini dapat terjadi karena penggunaan sistem tanda yang kompleks dan pemaknaan yang hanya sebatas pada makna lugas atau makna leksikalnya (sebatas pada arti kata).

Penelitian ini menaruh minat yang tinggi terhadap penemuan kembali tanda-tanda dari SaintExupéry, terutama yang berkaitan dengan sisi kehidupan sosial (kehidupan masyarakat) manusia. Dengan demikian, penelitian ini menganalisis tanda dan pemaknaan tanda dalam novela Pangeran Cilik karya Antoine de Saint-Exupéry melalui pendekatan semiotika.

Effendi dalam Ruliana (2014) menjelaskan istilah komunikasi berasal dari bahasa Inggris, yaitu communication yang berasal dari bahasa Latin, communicatio, dan bersumber dari kata communis yang berarti sama. Sama di sini berarti sama makna. Ragam penggunaan istilah komunikasi dapat membingungkan. Orang yang tidak terbiasa dengan bidang ini akan bertanya apakah istilah tersebut memiliki batas. Komunikasi dapat dipandang sebagai nama disiplin, sekaligus label untuk fenomena. Komunikasi juga memiliki arti populer, profesional, dan praktis (Ruben dan Stewart, 2014).

Hasil dari studi klasik yang dilakukan dua pakar komunikasi, Frank Dance dan Carl Larson, mengidentifikasi 126 definisi komunikasi yang telah dipublikasikan (Ruben dan Stewart, 2014). Dalam sehari-hari, komunikasi mengacu pada tindakan yang terjadi ketika seseorang menyampaikan sebuah pesan kepada orang lain.

Pesan verbal menggunakan bahasa alfanumerik yang tercatat sebagai salah satu prestasi kemanusiaan yang paling mengesankan. Ada sekitar 10.000 bahasa dan dialek berbeda digunakan saat ini (Ruben dan Stewart, 2014).

Bahasa dapat dibayangkan sebagai kode atau sistem simbol yang digunakan untuk pesan-pesan verbal. Bahasa dapat didefinisikan sebagai sistem produktif yang dapat dialihkan dan terdiri atas simbol-simbol yang cepat lenyap (rapidly fading), bermakna bebas (arbitrary), serta dipancarkan secara kultural (Hockett, 1977 dalam DeVito, 2011).

Menurut Ruben dan Stewart (2014), ada tiga aspek komunikasi yang dapat dengan mudah diamati, yaitu orang, simbol, dan media atau teknologi. Simbol dapat berupa huruf, angka, benda, orang, ataupun tindakan yang berfungsi mewakili sesuatu yang lain selain simbol itu sendiri. Bahasa, seperti yang sudah dipaparkan di atas, adalah sebuah simbol yang digunakan dalam melakukan komunikasi verbal. Simbol yang berbentuk kata-kata dalam suatu bahasa yang mewakili konsep dan objek itu tidak memiliki alasan yang pasti mengenai bagaimana maknanya terhubung dengan simbol tersebut.

Komunikasi intrapersonal merujuk pada komunikasi yang terjadi pada diri sendiri. Komunikasi ini berupa dialog internal dan dapat 
terjadi bahkan ketika komunikasi dengan orang lain sedang berlangsung. Virginia Satir (1988) dalam West dan Turner (2013) berpendapat, bahwa walau dialog internal ini dipandang aneh oleh beberapa orang, namun dialog internal mampu memperkuat penghargaan diri (self-esteem) seseorang.

Manusia selalu melakukan pemaknaan berdasarkan simbol yang diperoleh dari orang lain maupun dari diri sendiri. Setiap individu membentuk makna melalui proses komunikasi. Pembentukan makna ini membutuhkan konstruksi interpretif. Kemampuan manusia membentuk simbol dan memaknainya telah menarik minat George Herbert Mead untuk menelitinya.

George Herbert Mead menyatakan bahwa orang bertindak berdasarkan makna simbolik yang muncul di dalam situasi tertentu. Pendapatnya ini kemudian menjadi cikal bakal Teori Interaksi Simbolik (Symbolic Interaction Theory). Nama teori ini sendiri diberikan oleh murid Mead, yaitu Herbert Blumer (West dan Turner, 2013).

Menurut Herbert Blumer, ada tiga asumsi dasar dalam Teori Interaksi Simbolik (West dan Turner, 2013: 99). Pertama, manusia bertindak terhadap manusia lain berdasarkan makna yang diberikan orang lain kepada mereka. Contohnya, seseorang yang bekerja di lingkungan baru akan menginterpretasikan pengalaman kerjanya dengan rekan kerja lain. Orang itu akan menganggap rekan kerjanya memiliki pengalaman yang lebih banyak karena masa kerja yang lebih lama di perusahaan itu. Makna yang diberikan pada simbol merupakan hasil dari interaksi sosial yang menggambarkan kesepakatan dalam menggunakan makna pada simbol itu.

Kedua, makna diciptakan dalam interaksi antarmanusia. Blumer (1969) dalam West dan Turner (2013) menjelaskan bahwa ada tiga cara menjelaskan asal sebuah makna. Cara pertama memandang bahwa makna adalah sesuatu yang intrinsik dari suatu benda, seperti sebuah buku sudah jelas adalah sebuah buku. Cara kedua melihat makna dibawa kepada benda oleh seseorang bagi siapa benda itu bermakna. Cara ini mendukung pandangan bahwa makna terdapat di dalam orang, bukan pada benda. Cara ketiga melihat makna sebagai sesuatu yang terjadi di antara orangorang. Makna adalah ciptaan melalui pendefinisian aktivitas manusia ketika berinteraksi.

Ketiga, makna dimodifikasi melalui proses interpretif. Menurut Blumer (1969) dalam West dan Turner (2013), ada dua langkah dalam proses interpretif. Langkah pertama adalah menentukan benda-benda yang mempunyai makna. Kemudian langkah kedua melibatkan pelaku atau orang yang menginterpretasi untuk memilih, mengecek, dan melakukan transformasi makna di dalam konteks makna itu berada.

Berbeda dengan komunikasi intrapersonal, komunikasi interpersonal merupakan komunikasi antara dua orang atau lebih (kelompok kecil). Komunikasi pada tahap ini mulai terbentuk konsep relasi atau hubungan antarmanusia.

W. Barnett Pearce dan Vernon Cronen berpendapat bahwa aturan-aturan memainkan peranan penting dalam membantu manusia untuk berkomunikasi dan menginterpretasikan apa yang dikomunikasikan orang lain. Pendapat mereka kemudian dikenal sebagai teori Manajemen makna terkoordinasi(Coordinated Management of Meaning). Manajemen makna terkoordinasi merujuk pada bagaimana individu-individu menetapkan aturan untuk menciptakan dan menginterpretasikan makna dan bagaimana aturan-aturan itu terjalin dalam komunikasi yang maknanya dikoordinasikan (West dan Turner, 2013).

West dan Turner, (2013) mengasumsikan manajemen makna terkoordinasi ke dalam tiga bentuk, yaitu:

Pertama, manusia hidup dalam komunikasi. Asumsi ini memandang komunikasi menjadi hal yang mendasar dalam hidup manusia. Komunikasi membuat interaksi yang akhirnya membentuk situasi sosial.

Kedua, manusia saling menciptakan realitas sosial. Menurut Cronen, Chen, dan Pearce (1988) dalam West dan Turner (2013), individu-individu berkomunikasi untuk mengekspresikan emosi mereka dan untuk merujuk pada dunia atau peristiwa atau objek di sekeliling mereka. Semua itu dikonstruksikan dalam proses komunikasi. Konstruksionisme sosial adalah kepercayaan bahwa individu-individu saling menciptakan realitas sosial mereka yang baru. Realitas sosial merupakan pandangan seseorang mengenai bagaimana makna dan tindakan sesuai dengan interaksi interpersonalnya.

Ketiga, transaksi informasi bergantung kepada makna pribadi dan interpersonal. Makna pribadi dipandang sebagai makna yang dicapai ketika seseorang berinteraksi dengan orang lain sambil membawa pengalamannya ke dalam interaksi itu. Bila dua orang itu sepakat mengenai interpretasi satu sama lain, maka akan tercapai makna interpersonal. Makna pribadi dan makna interpersonal biasa didapatkan dalam percakapan.

Dalam kehidupan sosial, manusia selalu bertemu dengan tanda-tanda, baik itu tanda alamiah maupun tanda buatan. Tanda-tanda ini digunakan untuk berkomunikasi baik antarmanusia maupun manusia dengan lingkungannya. Tanda-tanda harus dimaknai supaya terjadi komunikasi yang efektif. Untuk memahami tanda atau pemaknaan tanda tersebut, diperlukan suatu ilmu untuk mempelajarinya.

Rusmana (2005) dalam Vera (2014) mengemukakan suatu studi tentang bagaimana masyarakat memproduksi makna dan nilai-nilai dalam sebuah sistem komunikasi disebut semiotika. Semiotika berasal dari bahasa Yunani, yaitu kata seemion, yang berarti tanda.

Peirce mengatakan bahwa tanda itu sendiri merupakan contoh dari Kepertamaan, objeknya adalah Kekeduaan, dan penafsirnya merupakan contoh dari Keketigaan. Sesuatu yang dipakai supaya suatu tanda bisa berfungsi disebut penanda atau 
ground atau sign, objek tetap disebut sebagai object, dan penafsirnya adalah interpretant. Ketiga ini membentuk sebuah hubungan triadik. Berdasarkan hubungan ini juga, Peirce membagi-bagi tanda menjadi berbagai jenis.

Pertama, tanda berdasarkan penandanya (ground) adalah qualisign, sinsign, dan legisign. Kedua, tanda berdasarkan objeknya adalah icon, indeks, dan symbol. Ketiga, tanda berdasarkan penafsirnya (interpretant) adalah rheme, dicent sign (dicisign), dan argument.

1. Tanda berdasarkan penanda:

a. Qualisign: tanda yang berhubungan dengan kualitas.

b. Sinsign: tanda yang berhubungan dengan eksistensi aktual benda atau peristiwa.

c. Legisign: tanda yang berhubungan dengan norma atau kaidah.

2. Tanda berdasarkan objek:

a. Icon: tanda yang menunjukkan hubungan kemiripan antara penanda dan petanda.

b. Index: tanda yang menunjukkan hubungan sebab-akibat antara

penanda dan petanda.

c. Symbol: tanda yang menunjukkan hubungan antara penanda dan

petanda berdasarkan konvensi atau perjanjian masyarakat.

3. Tanda berdasarkan penafsir:

a. Rheme: tanda yang memungkinkan penafsir menafsirkan berdasarkan pilihan.

b. Dicisign: tanda yang memungkinkan penafsir menafsirkan berdasarkan kenyataan.

c. Argument: tanda yang memungkinkan penafsir menafsirkan berdasarkan alasan tertentu atau kaidah yang ditetapkan.

Secara umum, analisis semiotika Peirce dapat dilakukan dengan menganalisis sign, object, dan interpretant saja. Bila ingin meneliti lebih lanjut terhadap suatu tema dari sisi tertentu, misalnya object barulah diperinci hingga icon, index, dan symbol.

Pengertian novela dalam Kamus Besar Bahasa Indonesia (KBBI) adalah kisahan prosa rekaan yang lebih panjang dan lebih kompleks daripada cerita pendek, tetapi tidak sepanjang novel. Di Indonesia, novela disebut juga sebagai novelet, sedangkan di Amerika, novela dibedakan dari novelet. Walau belum ada kesepakatan dari para ahli sastra atau bahasa, namun secara umum novela memiliki jumlah kata antara 17.500 sampai 40.000 kata dan novelet memiliki jumlah kata antara 7.500 sampai 17.500 kata.

Pangeran Cilik adalah judul terjemahan dalam bahasa Indonesia untuk novela Le Petit Prince. Novela ini ditulis oleh Antoine de Saint-Exupéry di Prancis pada tahun 1943 ketika diasingkan ke Amerika. Nama Saint-Exupéry melambung melalui karya ini. Tahun-tahun sesudahnya, Pangeran Cilik banyak diadaptasi ke berbagai media, seperti edisi audio, novel grafik, drama panggung, drama radio, tayangan televisi, anime, hingga film layar lebar.

\section{Metodologi Penelitian}

Penelitian ini bersifat kualitatif-deskriptif. Data teks penelitian ini adalah novela Le Petit Prince karya Antoine de Saint-Exupéry edisi bahasa Indonesia. Edisi tersebut diterjemahkan oleh Henri ChambertLoir dengan judul Pangeran Cilik dan diterbitkan oleh Gramedia Pustaka Utama pada tahun 2011. Penulis menggunakan edisi cetakan kedua yang terbit tahun 2015.

Dalam penelitian kualitatif, yang menjadi instrumen penelitian adalah peneliti sendiri. Oleh karena penelitian ini bersifat kualitatif, maka instrumen penelitian ini adalah peneliti sendiri. Peneliti meningkatkan kredibilitas data dengan memperpanjang waktu pengamatan. Selain itu juga meningkatkan ketekunan, artinya melakukan pengamatan dengan lebih cermat dan berkesinambungan pada menemukan tanda-tanda dan pemaknaan terhadap novela Pangeran Cilik. Dalam uji transferabilitas, Peneliti menyusun penelitian dengan memberikan uraian rinci, jelas, dan sistematis pada tanda-tanda dalam novela Pangeran Cilik sehingga orang lain akan lebih memahami hasil penelitian. Uji dependabilitas dan konfirmabilitas mirip, sehingga dapat dilakukan bersamaan. Peneliti berupaya konsisten dalam hasil penelitian dan terbuka tentang proses penelitian sehingga orang lain dapat melakukan penilaian terhadap hasil penelitian.

\section{Hasil Dan Pembahasan}

Novela Pangeran Cilik (Le Petit Prince) merupakan sumber utama dalam penelitian semiotika ini.

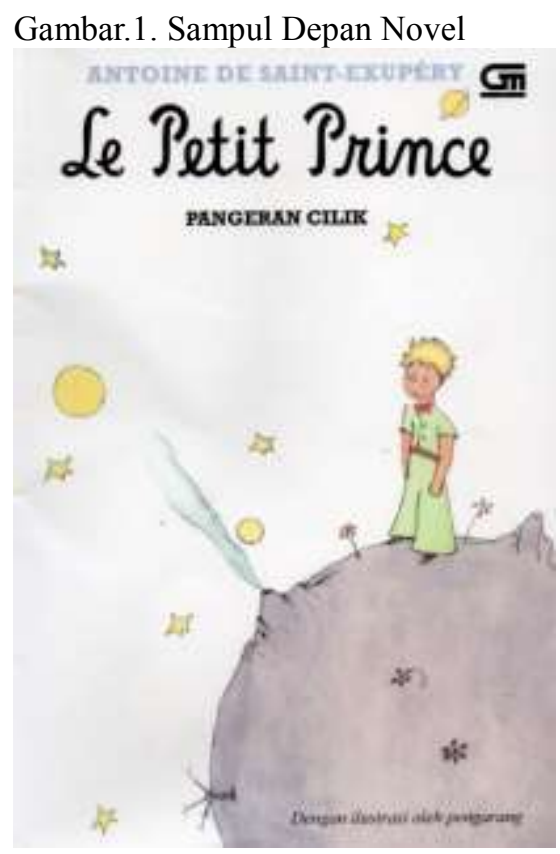

Penelitian yang difokuskan pada tanda-tanda khususnya tanda-tanda yang berupa gambar. Sedikitnya ditemukan tiga belas buah tema tanda 
yang dianalisis dalam penelitian ini.

Teori Interaksi Simbolik, seperti yang sudah dijelaskan pada bab sebelumnya, memiliki tiga asumsi teori. Pertama, manusia bertindak terhadap manusia lain berdasarkan makna yang diberikan orang lain kepada mereka. Kedua, makna diciptakan dalam interaksi antarmanusia. Ketiga, makna dimodifikasi melalui proses interpretif.

Pada bab kajian pustaka telah dijelaskan bahwa manajemen makna terkoordinasi juga memiliki tiga asumsi dasar. Pertama, manusia hidup dalam komunikasi. Asumsi ini memandang komunikasi menjadi hal yang mendasar dalam hidup manusia. Komunikasi membuat interaksi yang akhirnya membentuk situasi sosial.

Kedua, manusia saling menciptakan realitas sosial. Menurut Cronen, Chen, dan Pearce (1988) dalam West dan Turner (2013), individu-individu berkomunikasi untuk mengekspresikan emosi mereka dan untuk merujuk pada dunia atau peristiwa atau objek di sekeliling mereka. Semua itu dikonstruksikan dalam proses komunikasi. Konstruksionisme sosial adalah kepercayaan bahwa individu-individu saling menciptakan realitas sosial mereka yang baru. Realitas sosial merupakan pandangan seseorang mengenai bagaimana makna dan tindakan sesuai dengan interaksi interpersonalnya.

Ketiga, transaksi informasi bergantung kepada makna pribadi dan interpersonal. Makna pribadi dipandang sebagai makna yang dicapai ketika seseorang berinteraksi dengan orang lain sambil membawa pengalamannya ke dalam interaksi itu. Bila dua orang itu sepakat mengenai interpretasi satu sama lain, maka akan tercapai makna interpersonal. Makna pribadi dan makna interpersonal biasa didapatkan dalam percakapan.

Berikut akan dijelaskan lebih lanjut mengenai ketiga belas tanda yang ditemukan dan dikaji dari sisi komunikasi intrapersonal dan interpersonal.

Tanda 1: Narator memikirkan kembali kejadian masa lalu. Narator menunjukkan gambar yang diinterpretasikan berbeda oleh tokoh orang dewasa dan mendapatkan nasihat untuk masa depan.

Intrapersonal: Saat memaknai gambar, terjadi dialog internal dalam diri tokoh orang dewasa yang menandai terjadinya komunikasi intrapersonal. Cerita alur mundur narator juga menunjukkan komunikasi dalam diri, yaitu proses memikirkan kembali kejadian masa lalu.

Interpersonal: Komunikasi interpersonal muncul ketika narator dan tokoh orang dewasa terlibat percakapan untuk menciptakan saling pengertian terhadap gambar tersebut.

Tanda 2: Narator menceritakan dirinya (yang sudah dewasa) terdampar di gurun pasir tanpa orang lain di sekelilingnya. Ia bersiap-siap mengerjakan semua perbaikan pesawat seorang diri.

Intrapersonal: Kenangan narator tentang masa lalu memunculkan dialog internal (komunikasi dengan diri sendiri).

Interpersonal: Tidak terjadi komunikasi interpersonal, karena komunikasi hanya terjadi sebagai dialog internal narator.

Tanda 3: Narator merasa keheranan melihat seorang bocah (Pangeran Cilik) di tengah gurun pasir tanpa terlihat tersesat ataupun sekarat.

Intrapersonal: Luapan emosi narator (keheranan) membuatnya berusaha memaknai asal-usul Pangeran Cilik. Terjadi komunikasi dalam diri untuk memaknai kehadiran Pangeran Cilik.

Interpersonal: Tidak terjadi komunikasi interpersonal, karena komunikasi hanya terjadi sebagai dialog internal narator.

Tanda 4: Pangeran Cilik meminta narator menggambarkan seekor domba. Narator memenuhi permintaan Pangeran Cilik, tapi gambarnya tidak memenuhi keinginan Pangeran Cilik. Gambar keempat (sebuah peti yang dibilang dalamnya 'ada domba') akhirnya sesuai permintaan Pangeran Cilik. Intrapersonal: Terjadi komunikasi intrapersonal saat narator memaknai 'domba' yang dimaksud oleh Pangeran Cilik. Ketika pemahaman 'domba' pertamanya tidak sesuai keinginan Pangeran Cilik, maka narator merekontruksi ulang makna 'domba' dalam pemikirannya untuk memenuhi permintaan Pangeran Cilik.

Interpersonal: Ketika narator mengikuti permintaan Pangeran Cilik, itu menunjukkan bahwa antara narator dan Pangeran Cilik terjadi komunikasi interpersonal. Walau 'domba' tersebut tidak sesuai makna pribadi Pangeran Cilik (Pangeran Cilik menginterpretasikannya sebagai domba yang sakit parah, biri-biri jantan, dan domba tua), narator merekontruksi makna 'domba' yang dipahaminya. Ketika keduanya sepakat dengan interpretasi 'domba' tersebut, maka terjadi makna interpersonal.

Tanda 5: Narator mempertanyakan asal-usul Pangeran Cilik namun tidak dijawab. Pangeran Cilik malah melamun dan merenungi 'domba' yang digambar narator.

Intrapersonal: Narator yang terus bertanya pada Pangeran Cilik secara otomatis sudah mengalami pergolakan dalam diri. Ia menyusun pertanyaan dalam hati dan dan mempertanyakan kelayakan pertanyaan itu. Intinya, sudah terjadi komunikasi dalam dirinya sebelum mulai bertanya pada Pangeran Cilik. Tindakan Pangeran Cilik melamun dan merenungi sesuatu menandai sedang terjadi komunikasi dalam dirinya.

Interpersonal: Pangeran Cilik tidak menjawab pertanyaan narator. Dapat dikatakan tidak terjadi komunikasi interpersonal karena tidak ada interaksi, artinya tidak ada proses pertukaran informasi dan saling memaknai antara keduanya.

Tanda 6: Narator menduga planet asal Pangeran Cilik. Kemudian bercerita tentang seorang penemu asteroid yang tidak dipercayai oleh seorang pun. Namun, setelah berganti pakaian yang lebih bagus, orangorang mengakui penemuannya. 
Intrapersonal: Dalam diri narator lagi-lagi mempertanyakan asal-usul Pangeran Cilik. Kali ini dia mulai menduga-duga. Proses menduga-duga ini merupakan sebuah komunikasi intrapersonal.

Interpersonal: Tidak terjadi komunikasi interpersonal karena tidak melibatkan kesepakatan makna interpersonal. Tidak ada dua orang yang sedang terlibat percakapan langsung untuk menciptakan makna bersama.

Tanda 7: Narator dan Pangeran Cilik berdebat tentang duri pada bunga. Masing-masing memaknai duri pada bunga secara berbeda.

Intrapersonal: Pemaknaan duri pada bunga menunjukkan narator dan Pangeran Cilik menginterpretasikan arti 'duri' dalam diri mereka. Interpretasi dalam diri ini juga merupakan sebuah komunikasi intrapersonal.

Interpersonal: Perdebatan pendapat antara narator dengan Pangeran Cilik menunjukkan sebuah pertukaran informasi. Pangeran Cilik tahu apa maksud dari narator, maka ia menentang interpretasi dari narator. Makna interpersonal tercapai, tapi tokoh tetap mempertahankan makna pribadi.

Tanda 8-13: Pangeran Cilik mengunjungi enam planet sebelum terdampar di planet Bumi. Ia bertemu berbagai orang dan terlibat percakapan dengan mereka semua.

Intrapersonal: Ada proses menciptakan makna pada setiap orang dalam diri Pangeran Cilik. Artinya, Pangeran Cilik berkomunikasi pada diri sendiri mengenai sifat dan kelakuan setiap orang yang ditemuinya.

Interpersonal: Interaksi dengan orang-orang yang berbeda menandai terjadinya pertukaran informasi. Pertukaran informasi diiringi dengan terbentuknya makna interpersonal di antara kedua orang. Sejauh Pangeran Cilik bertemu orang-orang di planet yang berbeda, komunikasi interpersonal terus terjadi.

Tanda 1, narator yang masih kecil tetap dipandang sebagai anak kecil, oleh karena itu, tokoh orang dewasa kurang memperhatikan sang narator. Tanda ini merefleksikan kehidupan nyata, yaitu kecenderungan orang dewasa bersikap superior dari anak kecil. Makna yang dibawa seorang anak kecil dan adalah makhluk yang lebih lemah dan polos daripada orang dewasa, karena interpretasi orang dewasa adalah demikian juga. Asumsi pertama Teori Interaksi Simbolik terlihat melalui hal ini.

Tanda 2 dan tanda 3 mencerminkan apa yang dimaksud dalam Manajemen makna terkoordinasi. Kedua hal menampilkan rasa hampa dalam hati narator karena berada di tempat terpencil dan sendirian. Kemudian merasa senang atas kehadiran manusia lain. Manusia memang membutuhkan komunikasi untuk melepaskan emosi dan bertukar infornasi.

Tanda 4 menampilkan narator yang sedang memenuhi keinginan tokoh Pangeran Cilik, yaitu menggambar seekor domba. Namun, domba yang digambar tidak sesuai harapan. Ada kala manusia yang satu tidak memahami keinginan manusia lain walau memahami isi pesan sekalipun. Makna diciptakan dalam interaksi manusia. Ketika makna tidak tercipta, maka ada modifikasi makna melalui proses interpretatif. Narator menggambar sebuah peti 'berisi' domba. Ia memodifikasi makna Pangeran Cilik melalui kemampuan interpretasinya. Dalam hal ini juga terjadi konstruksionisme sosial antara narator dan Pangeran Cilik. Mereka menyetujui makna tersebut berdasarkan tindakan interpersonal mereka.

Tanda 5 juga menampilkan hal yang sama seperti Tabel 4.1, yaitu perlakuan terhadap manusia lain melalui makna yang diperoleh. Narator memanggil Pangeran Cilik dengan 'Nak', karena merasa lebih tua darinya. Oleh karena itu juga, narator berani mendesak jawaban atas asal-usul Pangeran Cilik tanpa henti. Rasa percaya pada usia lawan bicara yang lebih muda mendorong sikap dominan dalam percakapan.

Tanda 6 juga menyinggung tentang interpretasi manusia yang satu terhadap yang lain. Seorang astronom dengan pakaian resmi ala Eropa terlihat lebih mengesankan dan dapat dipercaya dibandingkan astronom berpakaian badut. Penampilan menjadi begitu penting karena memberi kesan pertama terhadap orang lain. Manusia memaknai sesamanya melalui tanda yang diberikan. Hal ini sesuatu asumsi pertama dari Teori Interaksi Simbolik.

Tanda 7 memperlihatkan perbedaan pendapat antara narator dan Pangeran Cilik tentang bunga yang berduri. Dari sisi narator, bunga itu jahat karena berduri, ibarat manusia yang terlihat bagus dari luar, tapi ternyata memiliki sisi yang jahat juga. Berbeda dengan pandangan pangeran Cilik yang melihat duri sebagai sesuatu yang biasa. Sama seperti manusia ada sisi baik dan buruk tergantung bagaimana manusia lain memaknainya. Semua itu kembali ke masingmasing individu, seperti yang diasumsikan dalam Manajemen makna terkoordinasi bahwa ada makna pribadi yang melibatkan pengalaman. Bila makna pribadi kedua belah pihak bertemu, akan tercapai makna interpersonal.

Tanda 8 sampai tanda 13 menceritakan perjalanan Pangeran Cilik ke enam planet berbeda sebelum terdampar di planet ketujuh, Bumi. Pangeran Cilik bertemu orang-orang yang berbeda dan terlibat komunikasi yang berbeda juga. Berturut-turut ia bertemu seorang raja, seorang sombong, seorang pemabuk, seorang pengusaha, seorang penyulut, dan seorang ahli ilmu bumi. Setiap orang memiliki karakteristik berbeda, sehingga cara berkomunikasi pun berbeda-beda untuk orang. Dengan demikian, komunikasi menjadi hal yang mendasar dalam hidup manusia. Komunikasi membuat interaksi yang akhirnya membentuk situasi sosial.

Berdasarkan teori di atas, komunikasi intrapersonal dan interpersonal yang muncul dari pemaknaan atau interpretasi terhadap ketiga belas tanda pada novela Pangeran Cilik dapat diperinci 
dalam tabel berikut:

\section{KESIMPULAN}

Pangeran Cilik, sebagai salah satu fiksi yang paling banyak diterjemahkan, memiliki banyak tanda yang sulit dipahami. Tanda-tanda yang tersebar dalam teks dan gambar tersebut berupa tanda-tanda dari sisi kemanusiaan. Dari analisis yang dilakukan terhadap tanda-tanda yang ditemukan, ternyata ada komunikasi intrapersonal dan komunikasi interpersonal yang muncul dan mencerminkan asumsi dasar dari Teori Interaksi Simbolik dan manajemen makna terkoordinasi.

Teori Interaksi Simbolik memiliki tiga asumsi teori. Asumsi pertama, manusia bertindak terhadap manusia lain berdasarkan makna yang diberikan orang lain kepada mereka. Dalam analisis terhadap novela Pangeran Cilik, asumsi tersebut dapat dilihat pada saat narator berusaha mendesak informasi tentang asal-usul Pangeran Cilik (tnda 5), narator menyebut Pangeran Cilik dengan panggilan 'Nak'. Panggilan ini mengindikasikan bahwa narrator memaknai Pangeran Cilik sebagai anak kecil dan narator memiliki kedudukan yang lebih tinggi untuk mendesak informasi karena lebih tua.

Asumsi kedua, makna diciptakan dalam interaksi antarmanusia. Pada saat Pangeran Cilik menunjukkan gambar sebuah objek berwarna cokelat, tokoh orang dewasa belum memahami makna yang ingin disampikan Pangeran Cilik (Tanda 1). Setelah ditunjukkan gambar kedua (ada interaksi lebih lanjut), maka orang pun memahami maksud yang ingin disampaikan. Terciptanya makna ini karena interaksi antarmanusia.

Asumsi ketiga, makna dimodifikasi melalui proses interpretif. Narator jelas memodifikasi makna 'domba' yang diminta Pangeran Cilik setelah tiga ekor domba sebelumnya gagal memenuhi permintaan Pangeran Cilik (Tanda 4). Narator tidak lagi menginterpretasikan domba sebagai gambar seekor hewan setelah selalu ditolak Pangeran Cilik. Ia menginterpretasikan sebagai domba dalam peti supaya Pangeran Cilik dapat berinterpretasi sesuai keinginan sendiri.

Manajemen makna terkoordinasi juga memiliki tiga asumsi dasar. Asumsi pertama, manusia hidup dalam komunikasi. Setiap Pangeran Cilik mengunjungi sebuah planet, ia bertemu orang-orang yang memiliki sifat dan kelakuan yang berbeda (Tabel 4.8 - Tabel 4.13). Walau sifat dan kelakuan berbeda-beda, Pangeran dengan orang-orang itu juga terlibat dalam komunikasi. Komunikasi sudah mendasar bagi setiap manusia bila bertemu dengan manusia lain.

Kedua, manusia saling menciptakan realitas sosial. Realitas sosial merupakan pandangan seseorang mengenai bagaimana makna dan tindakan sesuai dengan interaksi interpersonalnya. Ketika narator memaknai duri adalah sifat jahat bunga, Pangeran Cilik menentangnya (Tabel 4.7). Pangeran
Cilik menentangnya karena interaksi interpersonalnya memaknai secara lain. Realitas sosial Pangeran Cilik terbentuk dari itu. Ia memandang duri hanya sebagai sifat pertahanan bunga belaka.

Ketiga, transaksi informasi bergantung kepada makna pribadi dan interpersonal. Bila dua orang itu sepakat mengenai interpretasi satu sama lain, maka akan tercapai makna interpersonal. Bukti ini terlihat ketika ketika narator memenuhi permintaan Pangeran Cilik menggambar domba. Walau 'domba' tersebut tidak sesuai makna pribadi Pangeran Cilik (Pangeran Cilik menginterpretasikannya sebagai domba yang sakit parah, biri-biri jantan, dan domba tua), narator merekontruksi makna 'domba' yang dipahaminya. Ketika keduanya sepakat dengan interpretasi 'domba' tersebut, maka terjadi makna interpersonal.

Jadi, dari hasil penelitian dan pembahasan di atas, terlihat bahwa novela Pangeran Cilik memiliki banyak ruang bagi pembaca untuk menginterpretasikan setiap teks dan gambar. Semua tanda yang ditemukan dalam novela tersebut mencerminkan asumsi dasar dari Teori Interaksi Simbolik dan Manajemen makna terkoordinasi.

Penelitian ini berfokus pada penemuan tanda dan memaknai tanda yang berhubungan dengan komunikasi intrapersonal dan interpersonal. Teori yang digunakan terbatas pada Teori Interaksi Simbolik dan Manajemen makna terkoordinasi, sehingga masih banyak ruang bagi peneliti lain yang ingin meneliti novela Pangeran Cilik. Saran dari peneliti, gunakanlah teori semiotika tokoh lain untuk menganalisis Pangeran Cilik atau menggunakan teori komunakasi lain atau bahkan kombinasi keduanya, sehingga menghasilkan penelitian dari sudut pandang yang lebih berbeda dari penelitian ini. Walau tipis, Pangeran Cilik memiliki banyak sisi yang bisa diekspos tergantung kreatifitas peneliti.

\section{Daftar Pustaka}

de Saint-Exupéry, Antoine (2011). Le Ptit Prince: Pangeran Cilik. Jakarta. Gramedia Pustaka Utama.

DeVito, Joseph A (2011). Komunikasi Antarmanusia. Tangerang. Karisma Publishing Group.

Kriyantono, Rachmat (2014). Teknik Praktis Riset Komunikasi. Jakarta. Kencana Prenada Media Group.

Ruben, Brent D., Lea P. Stewart (2014). Komunikasi dan Perilaku Manusia. Depok. Rajagrafindo Persada.

Santosa, Puji (2013). Ancangan Semiotika dan Pengkajian Susastra. Bandung. Angkasa.

Sobur, Alex (2013). Semiotika Komunikasi. Edisi Pertama. Bandung. Remaja Rosdakarya.

Sobur, Alex (2015). Analisis Teks Media. Bandung. 
Remaja Rosdakarya.

Sugiyono (2014). Metode Penelitian Kuantitatif, Kualitatif, dan $R \& D$. Bandung. Alfabeta.

Book chapter:

Ardial, H (2014). Paradigma dan Model Penelitian Komunikasi. Jakarta. Bumi Aksara.

Bajari, Atwar (2015). Metode Penelitian Komunikasi. Bandung. Simbiosa Rekatama Media.

Ricoeur, Paul (2014). Teori Interpretasi: Membelah Makna dalam Anatomi Teks. Yogyakarta. IRCiSoD.

Ruliana, Poppy (2014). Komunikasi Organisasi: Teori dan Studi Kasus. Depok. Rajagrafindo Persada.

Vera, Nawiroh (2014). Semiotika dalam Riset Komunikasi. Bogor. Ghalia Indonesia.

Wibowo, Indiwan Seto Wahyu (2013). Semiotika Komunikasi: Aplikasi Praktis Bagi Penelitian dan Skripsi Komunikasi. Jakarta. Mitra Wacana Media. 